\title{
Spatial and temporal patterns of plantation forests in the United States since the 1930s: an annual and gridded data set for regional Earth system modeling
}

\author{
Guangsheng Chen ${ }^{1}$, Shufen Pan ${ }^{1}$, Daniel J. Hayes ${ }^{2}$, and Hanqin Tian ${ }^{1}$ \\ ${ }^{1}$ International Center for Climate and Global Change Research and School of Forestry and Wildlife Sciences, \\ Auburn University, Auburn, AL, USA \\ ${ }^{2}$ School of Forest Resources, University of Maine, Orono, ME, USA \\ Correspondence to: Shufen Pan (panshuf@auburn.edu)
}

Received: 16 March 2017 - Discussion started: 5 April 2017

Revised: 29 June 2017 - Accepted: 3 July 2017 - Published: 1 August 2017

\begin{abstract}
Plantation forest area in the conterminous United States (CONUS) ranked second among the world's nations in the land area apportioned to forest plantation. As compared to the naturally regenerated forests, plantation forests demonstrate significant differences in biophysical characteristics, and biogeochemical and hydrological cycles as a result of more intensive management practices. Inventory data have been reported for multiple time periods on plot, state, and regional scales across the CONUS, but the requisite annual and spatially explicit plantation data set over a long-term period for analysis of the role of plantation management on regional or national scales is lacking. Through synthesis of multiple inventory data sources, this study developed methods to spatialize the time series plantation forest and tree species distribution data for the CONUS over the 1928-2012 time period. According to this new data set, plantation forest area increased from near zero in the 1930s to 268.27 thousand $\mathrm{km}^{2}$ in 2012 , accounting for $8.65 \%$ of the total forestland area in the CONUS. Regionally, the South contained the highest proportion of plantation forests, accounting for about $19.34 \%$ of total forestland area in 2012. This time series and gridded data set developed here can be readily applied in regional Earth system modeling frameworks for assessing the impacts of plantation management practices on forest productivity, carbon and nitrogen stocks, and greenhouse gases (e.g., $\mathrm{CO}_{2}, \mathrm{CH}_{4}$, and $\mathrm{N}_{2} \mathrm{O}$ ) and water fluxes on regional or national scales. The gridded plantation distribution and tree species maps, and the interpolated state-level annual tree planting area and plantation area during 1928-2012, are available from https://doi.org/10.1594/PANGAEA.873558.
\end{abstract}

\section{Introduction}

A forest plantation is defined as an area of introduced or native tree species established through planting or seeding for wood and/or non-wood forest products (i.e., industrial forests) or the provision of other ecosystem services (i.e., protective forests; FAO, 2005). In the conterminous United States (CONUS), all plantation forests are used for forest products (FAO, 2005, 2015). The United States is ranked as the second largest country in the world for plantation forest, accounting for about $8.5 \%$ of the total national forest area (or 12.72\% of timberland) (Oswalt et al., 2014; FAO, 2015).
Plantation forests in the CONUS are generally intensively managed, including practices such as the use of genetically improved seedlings, site preparation, nitrogen $(\mathrm{N})$ and phosphorus (P) fertilization, and pre-commercial thinning. These plantation forests could significantly reduce the pressure on natural forests to meet fiber and other wood product demands (Sedjo, 2001). Upper estimates suggest that world demand for wood could be met by harvesting $10 \%$ of the global forest area under intensive management (Oliver, 1999). In the CONUS, dependence on forest plantations to supply wood and non-wood products is increasing (Stanturf and Zhang, 2003). Plantation forests play a major role in current and 
anticipated future supplies of timber because of their high growth rates, easy operability, and intensive management (USDA Forest Service, 2011).

Due to intensive interventions of human activities, plantation forests are distinct from naturally regenerated forests. Plantation forests have more uniform stand structure characterized by even-aged stands, single or low diversity of tree species, and less understory vegetation. The simple stand structure is also often characterized by fixed spaces among planted trees, which could significantly reduce the competition for resources by more even allocation of nutrients, water, and light among dominant trees. At present, most of the planted tree seedlings in the CONUS are genetically improved through either selection of the best seed sources or seed orchard breeding (Fox et al., 2007). Site preparation (e.g., root excavation, soil disking and bedding, slash burning, herbicide and insecticide application, fertilizer use) is commonly used before and during plantation forest establishment (Fox et al., 2004; Jokela et al., 2010; Allen et al., 2005). During tree growth, forest plantations are often managed with fertilization, mid-rotation thinning, and weed control. In addition, plantation forests are more frequently harvested at a younger stand age as compared to naturally regenerated forests. These contrasting management practices relative to naturally regenerated forests significantly alter biogeochemical and hydrological cycles in plantation forests (Allen et al., 2005; Sun et al., 2006; Jokela et al., 2010; Achat et al., 2015a).

It is still a challenge to assess the feedbacks between human and natural systems due to the complexity of both systems (Chen et al., 2012). With increasing human interventions and the uniform ecosystem structure, plantation forests are an ideal managed ecosystem to characterize the coupling effects of human activities and natural environmental factors on biogeochemical and hydrological cycling on a large scale. Previous studies have reported the distinct, local-scale carbon, nitrogen, and water cycles in plantation forests as compared to naturally regenerated forests (e.g., Albaugh et al., 2012, 2015; Sun and Vose, 2016; Gyawali and Burkhart, 2015; Vose et al., 2012; Hoover et al., 2014). Although the importance of plantation forests has been recognized, a representation of plantation management practices in current Earth system models is lacking (e.g., Hayes et al., 2012; Tian et al., 2014; Pan et al., 2015), mainly due to few established relationships between management practices and ecosystem biogeochemical and hydrological cycling, as well as no available long-term and high-spatialresolution gridded plantation maps at regional and national scales (Escalante Fernandez et al., 2002). In the CONUS, the effects of tree planting and management practices on forest productivity, carbon sequestration, and greenhouse gas emissions are being monitored through various ongoing field experiments and measurement programs, including the USDA Forest Service Forest Inventory and Analysis (FIA) program, Forest Productivity Cooperative (FPC, http://forestproductivitycoop.net/), Plantation Management Research Cooperative (PMRC, http://pmrc.uga.edu/), Forest Modeling Research Cooperative (FMRC, http://www.fmrc. frec.vt.edu/), Forest Biology Research Cooperative (FBRC, http://www.sfrc.ufl.edu/fbrc/), and the PINEMAP observation network (http://pinemap.org/). These field observations build a solid basis for extending field- or local-level studies to regional or national scales through remote sensing, modeling, or statistical extrapolation methods. Such scalingup studies rely on a series of spatially explicit and longterm regional data sets including various management practices, plantation distribution maps, and information on environmental conditions. The critical first step is to generate long-term and spatially explicit plantation distribution maps. Therefore, in this study, we aim to develop long-term (19282012) forest plantation area and spatial distribution data for the CONUS through a synthesis of various inventory data sets across multiple scales. This data set can be used for ecosystem modeling and statistical extrapolations of productivity, carbon storage, greenhouse gas fluxes, and hydrological cycling in plantation forests, which will improve the estimation accuracy of greenhouse gas balance in the CONUS as well as advance our understanding of how intensive land management modulates climate-ecosystem feedbacks.

\section{Data and methods}

\subsection{The workflow}

Figure 1 shows the data sets collected in this study and the workflow for overall processes. At first, the initial collections of various inventory data (in gray color boxes, Fig. 1) on plot, state, subregional, and regional scales were used to develop the middle products (in black boxes), including gridded plantation forest fraction map and the state-level annual plantation area data. Then, these inventory data and middle products were integrated into the mechanistic program (in the circle; see Sect. 2.7 for more details) to determine spatial distributions of plantation forest area and tree species (our final products) during 1928-2012.

\subsection{Divisions of study area}

In this study, we collected and synthesized various data from different scales organized by division of the study area into several spatial units, as described here. The FIA reports (e.g., Smith et al., 2009) commonly divide the CONUS into eight ecological subregions (Fig. 2), which are further grouped into three regions (South, West, and North). These eight subregions are South Central, Southeast, North Central, Great Plains Intermountain, Pacific Northwest, and Pacific Southwest. 


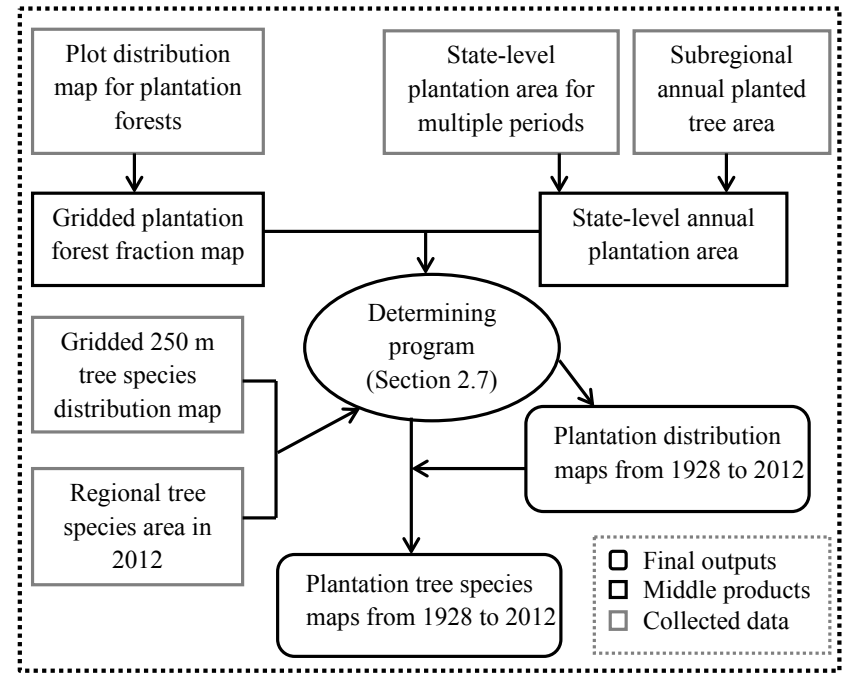

Figure 1. The workflow of overall processes in the generation of gridded $(8 \mathrm{~km} \times 8 \mathrm{~km})$ plantation distribution and tree species maps from 1928-2012.

\subsection{FIA plot-scale data and processing}

Due to the difficulty in distinguishing the optical reflectance of plantation forests from naturally regenerated forests, remote sensing products are not currently available to directly identify spatial locations of plantation forests across landscape scales. However, owing to thousands of FIA plots and the plantation forest records, here we are able to roughly determine the spatial locations, despite some inaccuracy due to assumptions and extrapolations.

We collected the USDA Forest Service FIA plot-level stand origin data (the variable is referred to as STDORGCD in the stand condition table of FIA data; https://www.fia. fs.fed.us/) for generating the spatial locations of plantation forests. The earliest available FIA plot data were collected in the mid-1980s. However, due to the inconsistent inventory time periods and missing observations of forest origin for some states, we chose only plot-level inventory data for the 5 years (2000-2004) when most of the states have records for forest origin. We used these data to represent the distribution of plantation forests in 2001, consisting of 16677 plots in total with plantation forest records (Fig. 3). According to FIA privacy policy, the geographic coordinates (i.e., latitude and longitude) of plots are swapped with nearby (within $0.8-1.6 \mathrm{~km}$ ), ecologically similar plots and thus do not represent the exact locations at the fixed latitude and longitude (O'Connell et al., 2017). Our spatial units for grid cells in this study are either 1 or $8 \mathrm{~km}$; thus, these deviations in spatial locations may not significantly influence our accuracy for assigned grid cell locations of plantation forests.

Based on the collected plots for plantation forests, we calculated the gridded fraction data using the method

$F=N \times A / B+\varepsilon$,

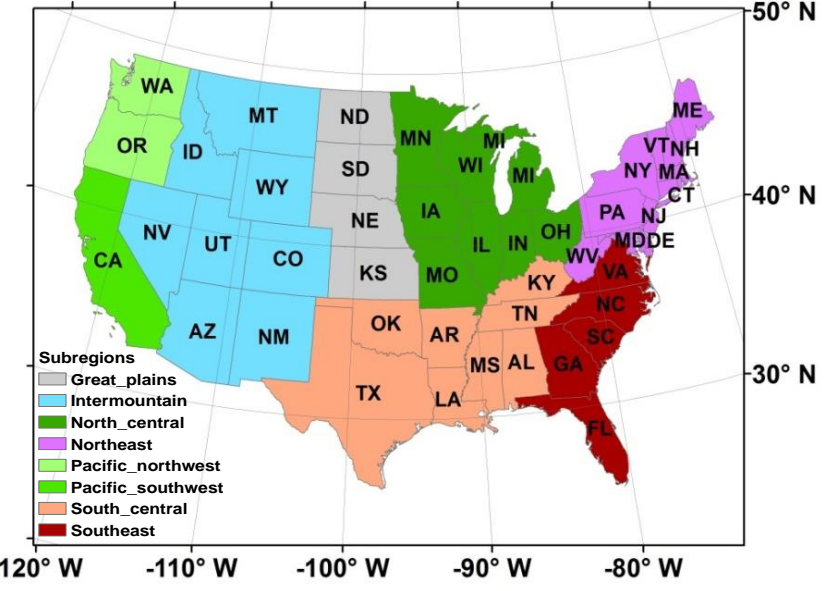

Figure 2. The division of the CONUS into eight subregions for data synthesis and analysis in this study. Note that three regions are further grouped in some reports, i.e., South (South Central and Southeast), North (Northeast and North Central), and West (Great Plains, Intermountain, Pacific Northwest, and Pacific Southwest). Data source: Smith et al. (2009).

in which $F$ is the fraction of plots with plantation forests within each grid cell; $N$ shows the plot numbers with plantation forest in each grid cell; $A$ is the represented area $(0.8 \mathrm{~km} \times 0.8 \mathrm{~km})$ of each FIA plot; $B$ is the grid cell area $(8 \mathrm{~km} \times 8 \mathrm{~km}) ; \varepsilon$ is a residue, which is used to add a small fraction (at the $0.01 \%$ scale) to the grid cells with the same plot numbers $(N)$ and calculated based on the percentage of forest $(\% \times 0.0001)$ from NLCD2001 land cover data (http: //www.mrlc.gov/nlcd01_data.php). The finally calculated $F$ of each grid cell will be a unique value, which is shown in Fig. 4.

\subsection{County-, state-, and region-scale inventory data}

The inventory-based plantation forest area data on three spatial scales were collected to generate the gridded data set. First, county-level data from 2007 were collected to evaluate the performance of the generated grid-scale plantation forest area for counties. Second, state-level inventory data of plantation forest area for eight time periods (i.e., 1952, 1962, $1970,1982,1989,1999,2007$, and 2012) for the states in the South Central and Southeast were collected from the southern forest resource assessment report (Wear and Greis, 2002). Due to a lack of available historical data, our data set includes only years 2007 and 2012 for other states in the CONUS, as collected from USDA Forest Service reports (Smith et al., 2009; Oswalt et al., 2014). Third, the subregional (Fig. 1) annual planted tree area data from 1928 to 2011 were collected from Oswalt et al. (2014), in which the data from 2004 to 2011 were not available for most subregions except for the Southeast and South Central (Fig. 5). Annual tree planting area in the Southeast and South Central exhibited two quickly 


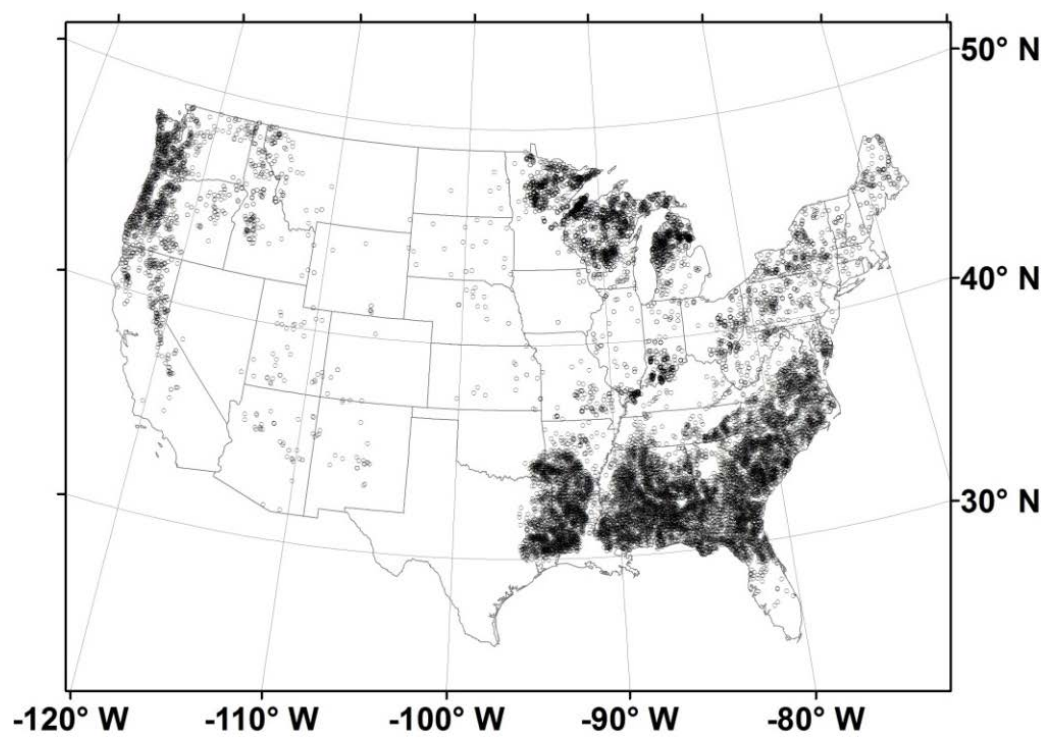

Figure 3. FIA plot distributions (16677 plots in total) with plantation forest in the conterminous US during 2000-2004.

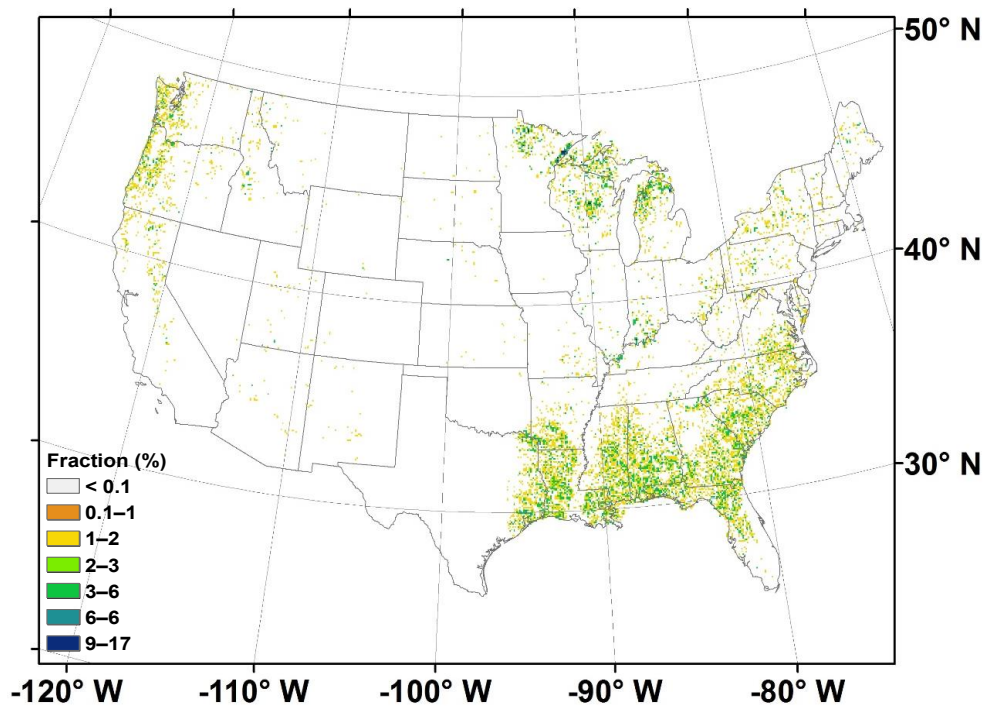

Figure 4. Fraction of the plots with plantation forests in the grid cells at a spatial resolution of $8 \mathrm{~km} \times 8 \mathrm{~km}$.

increasing periods during 1945-1960 and 1966-1989 and no obvious tendency after 1990.

\subsection{Forest species data}

We collected forest-cover-type data on a spatial scale of $250 \mathrm{~m}$ generated by the USDA Forest Service FIA program and Remote Sensing Applications Center (https://www.fia. fs.fed.us/library/maps/). In total, 113 major tree species are divided in this data set. According to the plantation forest species area data for the three regions (i.e., South, North, and West) in Oswalt et al. (2014), we identified the major plantation forest species in the CONUS and further re- grouped into 11 major tree species groups, i.e., loblollyshortleaf pine, longleaf-slash pine, Douglas fir, white-redjack pine, ponderosa pine, spruce-fir-larch-hemlock, oakhickory-gum-cypress, elm-ash-cottonwood, maple-beechbirch-aspen, other hardwoods (including juniper, palm, mangrove, and others), and other pine species (including redwood, sand pine, western white pine, lodgepole pine, and others). Using the aggregation method in ArcGIS, the $250 \mathrm{~m}$ forest-type data were then aggregated to continuous values representing the fraction of each species group per $8 \mathrm{~km}$ grid cell. Based on the same methods in Sect. 2.7, we generated a map with the Boolean $(0,1)$ data for each forest-type group, with 1 representing the grid cells occupied by this forest 


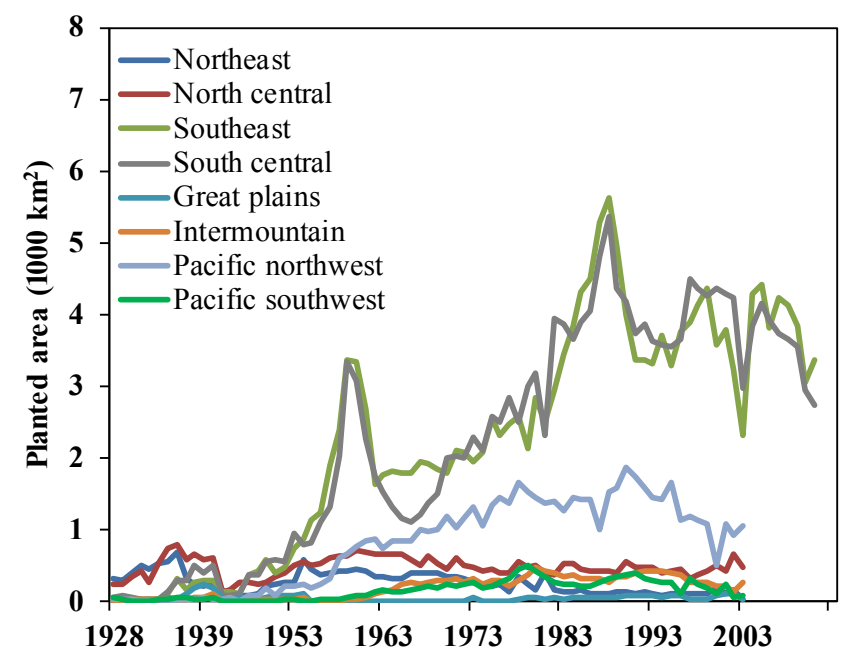

Figure 5. Interannual variations in planted tree area $\left(1000 \mathrm{~km}^{2} \mathrm{yr}^{-1}\right)$ for eight subregions in the CONUS during 1928-2011 (data source: Oswalt et al., 2014). Note that the data for the Southeast and South Central are extended to 2011, while the continuous inventory data end in 2003 and resume in 2011 for other subregions.

type. The forest-type data were then overlaid with our generated plantation maps (Sect. 2.7) to obtain the $8 \mathrm{~km}$ resolution plantation-forest-type information. In the report of Oswalt et al. (2014), there is a plantation group of non-stocked forest type (3.88 thousand $\mathrm{km}^{2}$ in total), which mainly includes young plantation stands and seedling orchards that have yet to reach a crown density of $10 \%$ (https://www.fs.fed.us/ne/ fia/methodology/def_ip.htm). We were unable to directly assign it to the regrouped 11 plantation types; instead, we compared the fractions of all 11 plantation types in the grid cells with non-stocked, and assigned the plantation types with the highest fractions within these grid cells.

The USDA forest-type map was also generated based on the FIA plot data. Furthermore, the majority of the trees in plantation forests of the CONUS are native species (Escalante Fernandez et al., 2002; FAO, 2005), which can help reduce the pixel contamination due to the neighboring grid cells. Therefore, the forest-type map matches well with our generated plantation distribution data. Using the loblollyshortleaf species group as an example, Fig. 6 illustrates the generation of plantation tree species groups based on the fractional data and regional inventory area of each tree species group.

\subsection{Generation methods for state-level plantation area}

We have collected state-level plantation area data for eight periods: 1952, 1962, 1970, 1982, 1989, 1999, 2007, and 2012, but we lack data to capture interannual patterns within these periods. To make the state-level data consistent among all periods, we post-processed these inventory data. In this study, we assumed that the plantation forest area did not decrease with time for each state; thus, if the data from the previous period (e.g., 2007) were less than the data in the present period (e.g., 2012), the data in the present period (e.g., 2012) were then replaced by the previous ones (e.g., 2007). We assumed that the data in 2007 are the actual plantation area (i.e., assume the inventory data in this year are accurate) to control the post-processing. Therefore, the plantation area in other periods could not be exactly the same with the collected inventory data. The annual tree planting area in 1928 was used as the control of initial plantation area $\left(A_{0}\right)$, and the other eight time periods for the South and Southeast were assigned as $A_{1}$ to $A_{8}$. The other states that had data for only two periods (2007 and 2012) were assigned as $A_{1}$ and $A_{2}$. We integrated annual planted tree area data for eight subregions with state-level plantation area data to linearly interpolate distribution pattern during 1928-2012 for each state. The interpolation method is as follows:

$C_{\text {sum }}=\sum_{j=1}^{N} C_{j}$

$\mathrm{TA}_{i}=A_{p}+\left(A_{p+1}-A_{p}\right) \times \frac{C_{j}}{C_{\text {sum }}}$,

in which $i$ is the year (1928-2012), $\mathrm{TA}_{i}$ is the generated targeted plantation area in year $i, p$ is the time periods $(0-8$ for the South and Southeast states and 0-2 for other states), $A_{i}$ is the inventory plantation area at year $i, A_{p+1}$ is the inventory plantation area at time period $p+1, N$ is the total numbers of years during inventory period $p$ to $p+1, j$ is the number of year $(0-N)$ during inventory period $p$ to $p+1$ for plantation forest area, $C_{\text {sum }}$ is the total planted tree area during inventory period $p$ to $p+1$, and $C_{j}$ is the planted tree area at time $j$ during period $p$ to $p+1$.

\subsection{Methods for spatialization of gridded plantation area and tree species data}

Boolean $(0,1)$ plantation data were developed at $8 \mathrm{~km} \times 8 \mathrm{~km}$ spatial resolution (125718 grid cells), with 0 denoting naturally regenerated forest and 1 denoting plantation forest. Considering the limited plot numbers, we chose this coarse spatial resolution for plantation data. In addition, the Boolean data at a moderate $(8 \mathrm{~km})$ spatial resolution might be adequate to apply in future modeling or statistical studies since many other available environmental data, such as climate, land use, and atmospheric composition, are coarser or similar to $8 \mathrm{~km}$. We only have one single time point of plantation forest fraction (Sect. 2.3). To track back the historical spatial patterns based on the state and subregional inventory data, we have to assume that the plantation forests will not be converted back to naturally regenerated forests, i.e., if this grid cell was identified as plantation in 1928, it will always have been plantation since then. 

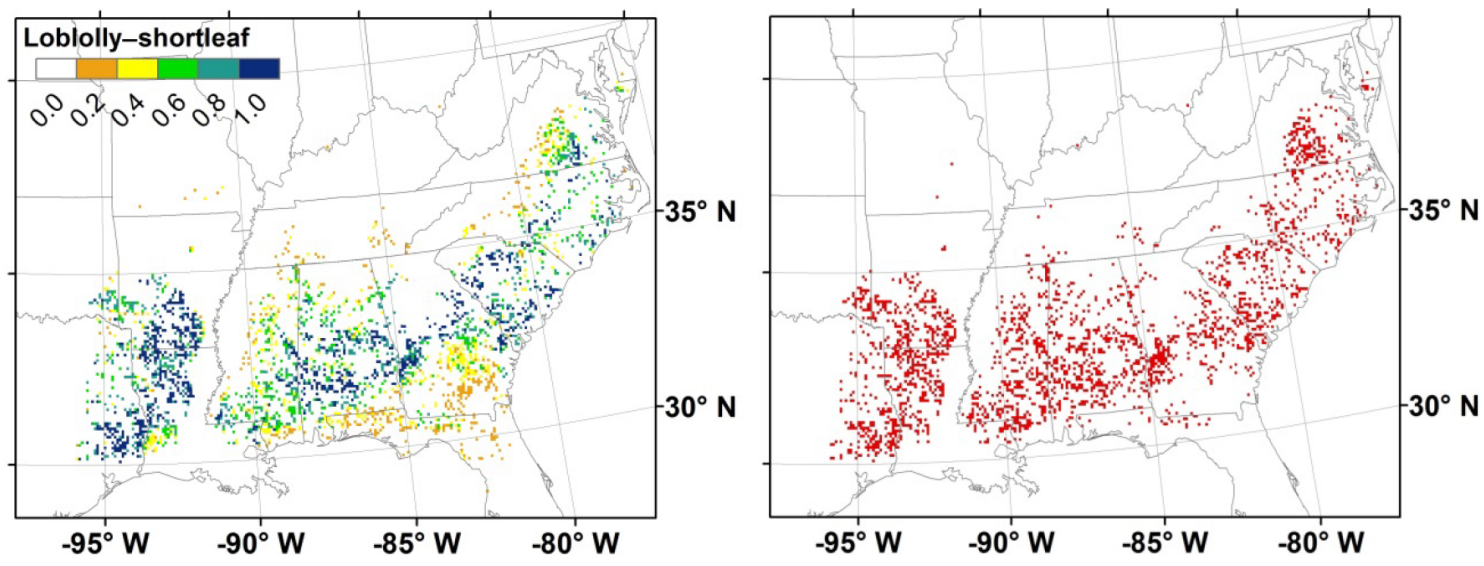

Figure 6. Illustration of the generation of spatial distribution maps for tree species groups in terms of fractional data and regional inventory area data using loblolly-shortleaf pine as an example. Left panel: fraction of loblolly-shortleaf pine species group in each grid cell; right: identified final grid cells with loblolly-shortleaf pine.

Figure 7 describes the procedure to produce the spatial distribution maps of plantation forests. The state-level plantation forest area data set $\left(\mathrm{TA}_{i}\right)$ generated in Sect. 2.4 is the targeted plantation area for this specific state $i$. To determine if a grid cell is plantation forest, the fraction data set for grid cell $j$ in state $i\left(F_{i j}\right)$ generated in Sect. 2.3 is used. The principle is to progressively narrow down the fraction threshold ranges $\left(T_{i, \min }\right.$ and $\left.T_{i, \max }\right)$ to a fixed threshold value $\left(T_{i}\right)$, and based on this determined threshold, we ultimately reach the targeted plantation area for state $i$. At the first-round run of the program, a minimum threshold 0 and maximum threshold 1 are assigned. The $T_{i}$ is calculated as the average of $T_{i, \max }$ and $T_{i, \min }$. Based on this $T_{i}$ value, we run a program to check if the fraction data $\left(F_{i j}\right)$ is higher than $T_{i}$ for each grid cell within the specific state. If yes, then this grid cell is assigned as a value of Boolean $1\left(B_{i j}=1\right)$; otherwise, it is assigned as $0\left(B_{i j}=0\right)$. The $B_{i j}$ values for all grid cells within this state are added to calculate the total plantation area $\left(A_{i}\right)$. If the total area is smaller than $\mathrm{TA}_{i}$, the program will assign $T_{i, \max }=T_{i}$; if the total area is larger than $\mathrm{TA}_{i}$, the program will assign $T_{i, \min }=T_{i}$. Based on the new $T_{i, \max }$ and $T_{i, \min }$, the program will go to the second-round run and repeat all processes above. After the second-round run, if the $A_{i}$ is still not equal to $\mathrm{TA}_{i} \pm 1 \mathrm{~km}^{2}$, the program will run more rounds until $A_{i}=\mathrm{TA}_{i} \pm 1 \mathrm{~km}^{2}$. Under this condition, the generated state-level plantation area is very close to the targeted plantation area at the end. Finally, the $B_{i j}$ maps ( 0 and 1 Boolean values) represent the spatial distributions of plantation forests in this specific state $i$. This program was run for all the CONUS states and eventually resulted in the spatially explicit plantation forest distribution maps from 1928 to 2012.

Based on the regional inventory data and gridded fractional data for individual plantation tree species groups (Sect. 2.5), we also applied the methods above to generate the plantation tree species group maps during 1928-2012.

\section{Results and discussion}

\subsection{Plantation forest area and temporal variations}

Plantation forest area in the CONUS showed a continuous increase from 1928 to 2012, with the largest increasing rates during the 1950s (176\% per decade) and 1960s (86\% per decade) and the least during the 1970s (Fig. 8). Plantation forest area was 268.27 thousand $\mathrm{km}^{2}$ in 2012 , accounting for $8.65 \%$ of CONUS forestland area and $2.93 \%$ of the total land area. The global plantation area was reported to account for about $6.95 \%$ of the total forestland area (FAO, 2015), which is lower than the fraction in the CONUS. The increasing rate showed a slight leveling-off trend during recent decades; however, the total plantation area still increased by $36.81 \%$ from 2000 to 2012, with this time period having the largest absolute increase $\left(+72.16\right.$ thousand $\left.\mathrm{km}^{2}\right)$ in plantation area. The West region had the largest forest area (1.40 million $\mathrm{km}^{2}$; Oswalt et al., 2014) as compared to the North $\left(0.71\right.$ million $\left.\mathrm{km}^{2}\right)$ and South $\left(0.99\right.$ million $\left.\mathrm{km}^{2}\right)$; however, the South has had the highest plantation forest area since 1950, followed by the West since 1976. In 2012, the plantation forest area in the South, North, and West was $191.78,25.90$, and 50.55 thousand $\mathrm{km}^{2}$, respectively. The plantation forest area accounted for $19.34 \%$ of the total forest area in the South, while only about $3.62 \%$ in both the North and West. Over the earlier time periods (1928-1950), the North had the highest plantation area. The West had the smallest plantation forest area before 1976, but it increased faster than the North and overpassed after 1976. The plantation area in the South has increased the fastest since 1950 as compared to the other two regions. The plantation area in the South and North maintained increasing rates in recent decades while the rate of increase in the West slowed down.

The smaller proportion of plantation forests in the West does not imply a greater potential for increasing plantation 


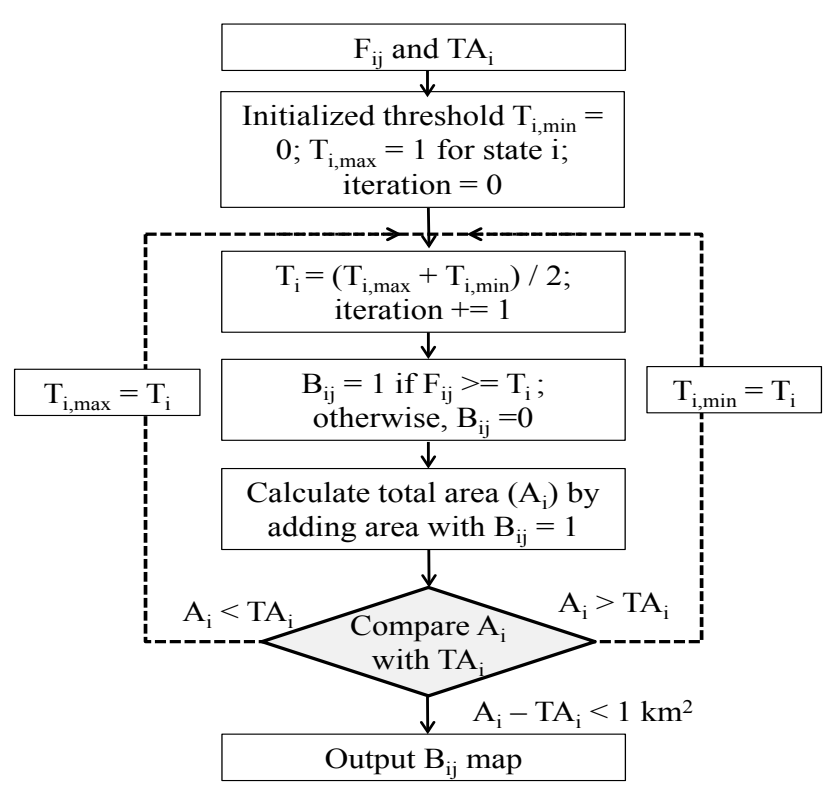

Figure 7. The procedure to identify the spatial distribution maps of plantation forests for each state based on grid cell fractional data and state-level inventory data, in which $i$ : state, $j$ : grid cell ID, $F_{i j}$ : fraction of plantation forest for grid cell $j$ in state $i, T_{i}$ : calculated threshold fraction for state $i, T_{i, \max }$ : identified maximum fraction threshold, $T_{i, \text { min }}$ : identified minimum threshold, $B_{i j}$ : plantation distribution represented by Boolean values $(0,1)$ for grid cell $j$ in state $i, A_{i}$ : calculated plantation area in state $i$, and $\mathrm{TA}_{i}$ : targeted plantation area in state $i$.

forest area in this region in the future because the mountainous terrains and relatively dry climate (the southern and central portions) are not suitable for tree planting and management. In addition, most of the forest area in the West belongs to public land (USDA Forest Service, 2014), which is managed for multiple uses and generally not managed as intensively for forest product yields as privately owned, profitoriented forest properties. The North region has a far smaller fraction of public forest than the West; however, the cooler climate may result in less productivity and thus restrain its potential in the wide spread of plantation forest area in the future (Escalante Fernandez et al., 2002). In contrast, although the South has a very high fraction of plantation forest and provides most of the wood and/or non-wood forest products for the CONUS, it still has a large potential for increasing plantation forest area, as also predicted by Wear and Greis (2002), in which they have projected increasing rates in plantation forest area with varied extents from about 14 to $57 \%$ from 2010 to 2040 under four future scenarios. Their predictions for the period from 1995 to 2010 ranged from about 9 to $19 \%$, which were far lower than the realistic increasing trend $(45 \%)$ as indicated by our study, implying an underestimated projection of future plantation forest area in the South. Wear and Greis (2012) updated their predictions and indicated increasing rates of 20 and $65 \%$ under the lowest

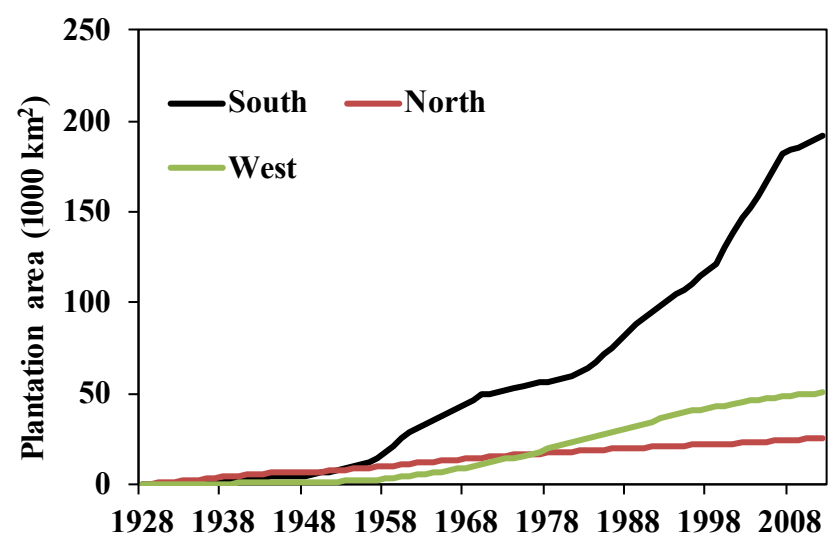

Figure 8. Total plantation forest area $\left(1000 \mathrm{~km}^{2}\right)$ for different regions in the CONUS during 1928-2012.

and highest scenarios, respectively, from 2010 to 2060 in the South. Based on our data in $2010\left(187.8\right.$ thousand $\left.\mathrm{km}^{2}\right)$, the highest estimation of total plantation area in 2060 would be 309.9 thousand $\mathrm{km}^{2}$, which accounts for about $31.30 \%$ of total forestland area in this region. The temporal and spatial changing patterns in the CONUS were primarily determined by the demands for wood products, the changes in policy and incentives, and food and bioenergy price and demands (Wear and Greis, 2012). The development of plantations was divided into three stages: initial stage (before 1946), acceleration (1946-1976), and steady growth (1977-present) (Zhang, 2004). During the initial stage, the major incentives were the government policies, such as the $1928 \mathrm{McSweeney-McNary}$ Act, 1924 Clarke-McNary Reforestation Act, and Agricultural Conservation Program (ACP, 1936). The acceleration stage was primarily driven by increasing wood product demand and price and decreasing food commodity price. The Soil Bank Program (SBP), which encourages agricultural abandonment to environmental conservation, was the most important government incentive during this period. During the steady growth stage, the declining cost of plantation establishment was the major incentive. Other incentives include tax reduction through the reforestation tax incentive provision (1980) and Tax Reform Act (1986), ACP (ended in 1995), Forest Incentive Program (FIP, 1974), and Conservation Reserve Program (CRP, 1986).

\subsection{Spatial distribution patterns}

Before the 1950s, there was only small plantation forest area (230 grid cells), mainly scattered throughout the South, Northeast, Pacific Northwest, and North Central (Fig. 9). The late 1950s were essentially marked as the beginning of extensive pine plantation establishment in the South (Frederick and Sedjo, 1991). The time period 1950-1970 had witnessed the fastest increasing rate of plantation forests; therefore, the plantation forests were widely spread across the South, the 


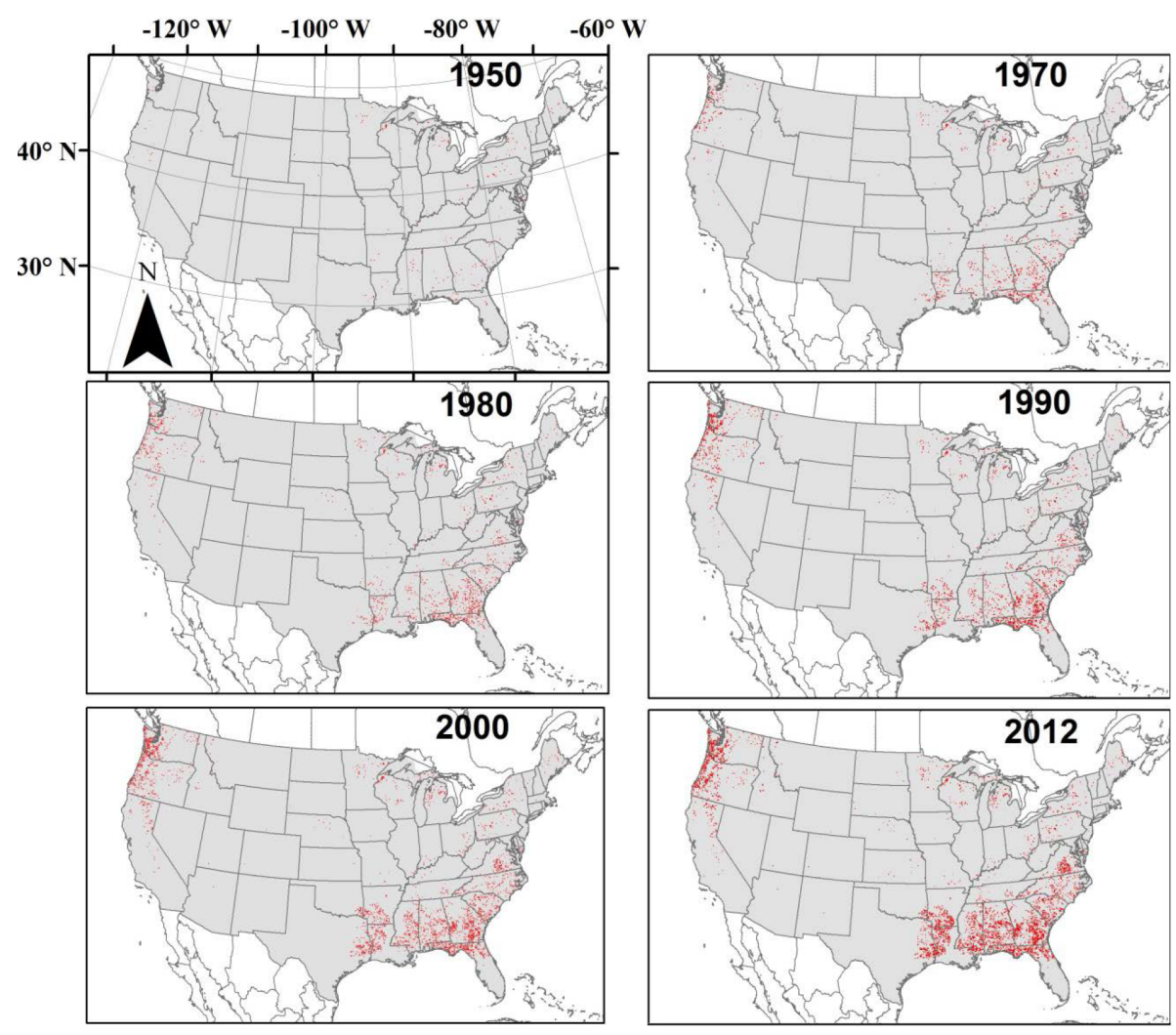

Figure 9. Spatial distributions for plantation forests during 1950, 1970, 1980, 1990, 2000, and 2012 at a spatial resolution of $8 \mathrm{~km}$ for the CONUS.

Northeast, and the Pacific Northwest. The spatial distribution patterns of plantation forests were quite similar among the time periods after 1980 and area expansions occurred within these three regions. Further analyses indicated that the 20 states with the largest plantation area accounted for about $96.32 \%$ of the total CONUS plantation area in 2012, and the top 10 states accounted for about $76.62 \%$ of the total (Fig. 9). Among the 20 states, GA had the highest plantation area, followed by AL, OR, and MS, while OK and TN had the smallest area. The plantation forest area accounted for $31.2,30.6,30.4,29.3$, and $28.4 \%$ of total forestland area in GA, LA, AL, MS, and FL, respectively. Although LA has lower total forestland area (about $59 \%$ of GA) as compared to the other four states, it had the second largest plantation proportion. Plantation area in these southern states was projected to continue increasing from the present to 2060 (Wear and Greis, 2012). Notably, the Pacific Northwest states of OR and WA had relatively high proportions of plantation forests (20.1 and $19.9 \%$, respectively), with OR ranked as the third largest state of forestland area in the CONUS, and they might have a greater potential for a continuing increase in plantation area in the future.

During 1990-2012, AL had the largest increase (238.0\%) in plantation area, followed by MS $(236.8 \%)$ and LA $(191.2 \%$, Fig. 10). These states had small increasing rates of
13.2, 5.49, and 5.77\%, respectively, during 1950-1990. In contrast, plantation area in GA, FL, and OR showed continuous and stable increasing trends during 1950-2012. Among the top 20 states, the absolute plantation area was the smallest in OK; however, this state exhibited a large increasing rate $(137.9 \%)$ during this period. In addition, the states of TX and AR also displayed a relatively high increasing rate. These two states might become major contributors to the increasing plantation area in the CONUS in the future since their forestland area is relatively larger and could sustain more conversions of plantations from naturally regenerated forestland. Conversely, several Northeast states (e.g., WI, MI, NY, and PA) and the Southeast state FL showed the smallest rates of increase.

\subsection{Plantation tree species}

Tree species is key information to estimate both tree endogenous growth rates as well as the responses of exogenous growth to environmental changes and management practices. To identify the tree species in the plantation forests during 1928-2012, the plantation maps were overlaid with the tree species distribution map in 2012 (Fig. 11). In the CONUS, almost all planted tree species are native species and planted for productive purposes (Escalante Fernandez et al., 2002; 


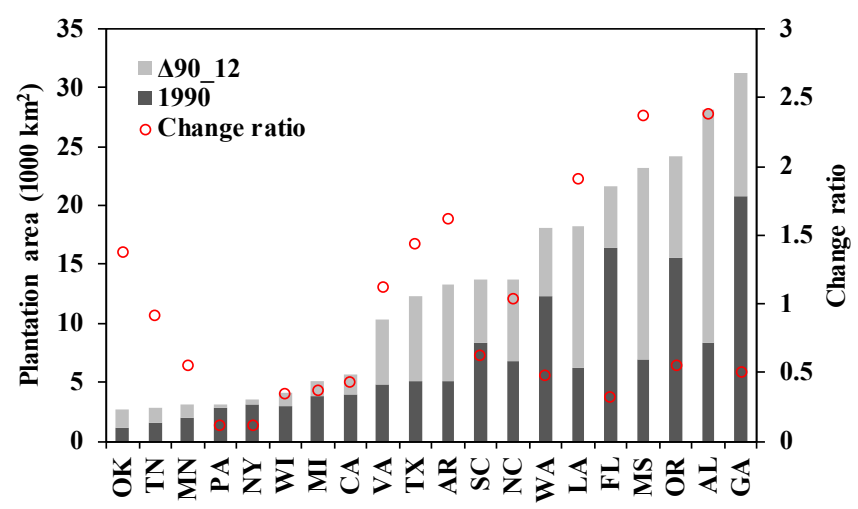

Figure 10. Plantation area in 1990 (dark gray), area change from 1990 to 2012 (light gray), and change ratio ( $\Delta 90 \_12 / 1990$; red circle) for the selected top 20 states with the largest plantation area in the CONUS.

FAO, 2005). In the South, over $69.2 \%$ of the planted tree species were loblolly-shortleaf pine, followed by longleafslash pine (15.6\%), oak-pine (7.5\%), and oak-hickory (Oswalt et al., 2014). The slash pine forests have less productivity than loblolly pine but generally produce higher-quality wood (Escalante Fernandez et al., 2002). Therefore, this species was widely planted in southern AL, GA, and northern FL. In the North, about $48.8 \%$ of the planted tree species were white-red-jack pine, followed by spruce-fir $(11.3 \%)$. The white-red-jack pine types are scattered across the North Central states, while spruce-fir mainly shows up in ME and MN. In the West (primarily Pacific Northwest), Douglas fir accounted for $60.3 \%$ of the planted tree species, followed by Oak-hickory-gum-cypress $(11.9 \%)$ and Ponderosa pine $(9.4 \%)$. Douglas fir is primarily located along the coastline in WA and OR. On a national scale, loblolly-shortleaf pine accounted for most $(49.45 \%)$ of the plantation forest area, followed by longleaf-slash pine $(11.04 \%)$ and Douglas fir $(11.17 \%)$.

\subsection{Plantation management practices and their impacts}

The plantation forests in the CONUS are mostly privately owned and about two-thirds of the plantations are timberland (Escalante Fernandez et al., 2002). Therefore, intensive management practices were widely applied to promote productivity, especially after 1990 (Fox et al., 2004, 2007; Stanturf et al., 2003). Generally, management intensity among regions is greatest in the South and lowest in the Northeast (Escalante Fernandez et al., 2002). The major plantation management practices include site preparation (e.g., soil disking, bedding, litter raking, and herbicide use), genetic improvement (e.g., breeding and seed tree selection), fertilization, thinning, prescribed fire, and harvesting (Vance et al., 2010; Fox et al., 2004). The late 1950s was regarded as the beginning of extensive pine plantations in the CONUS (Frederick and Sedjo, 1991; Vance et al., 2010). During the most recent
2 decades (1990-2009), pine plantations were harvested (including partial and clear-cut harvest) at a rate of about 3.15 thousand $\mathrm{km}^{2}$ per year in the CONUS (Smith et al., 2009). Thinning, site preparation, and slash burning area per year were $1.25,2.87$, and 2.70 thousand $\mathrm{km}^{2}$, respectively (Smith et al., 2009). About 6.47 thousand $\mathrm{km}^{2}$ of pine plantations was fertilized in 1999 alone, while about 40.47 thousand $\mathrm{km}^{2}$ in total has been fertilized in the South since 1969 (Fox et al., 2007).

Vance et al. (2010) synthesized the extent and benefits of multiple intensive management practices and the factors influencing productivity in the different subregions of CONUS. Fox et al. (2004) even indicated that multiple management practices would increase pine volume at harvest by over 4 times in the South. In addition to carbon dynamics, the intensive management practices were reported to significantly change the ecosystem hydrological and nitrogen cycles based on numerous field experiments and observations from various observational networks (e.g., FPC, FIA, FMRC, PMRC, FBRC, PINEMAP, AmeriFlux, and the Long Term Ecological Research Network (LTER)). These studies have addressed the ecological impacts of plantation forestry in terms of tree species and environmental conditions, as well as management regime, intensity, and frequency. Continued observational and experimental evidence of plantation forest function is critical to assess or predict the relationships between environmental changes, plantation management practices, and managed forest carbon, nitrogen, and water cycles. At present, it is highly likely for researchers to scale up the field or local experiments and observations to regional or national scales through remote sensing, modeling, or statistical extrapolation methods.

\section{Data availability}

The gridded $(8 \mathrm{~km} \times 8 \mathrm{~km})$ plantation distribution and tree species maps and state-level tree planting area and plantation forest area during 1928-2012 are available from https://doi.org/10.1594/PANGAEA.873558 (Chen et al., 2017). There are two data formats for gridded data: text/ASCII and ArcGIS GRID formats; an Excel format table is used to organize the annual tree planting area and total plantation area data for the 48 states in the conterminous US during 1928-2012. A supplemental file is added to show the plantation distribution maps in 1952, 1962, 1970, 1982, 1989, 1999, 2007, and 2012.

\section{Conclusions and outlooks}

This study developed an annual and spatially explicit data set for plantation forests in the CONUS during 1928-2012. The data set showed that plantation forests have increased rapidly since the 1960 s. While these increasing rates have stabilized during recent decades, there was still great poten- 


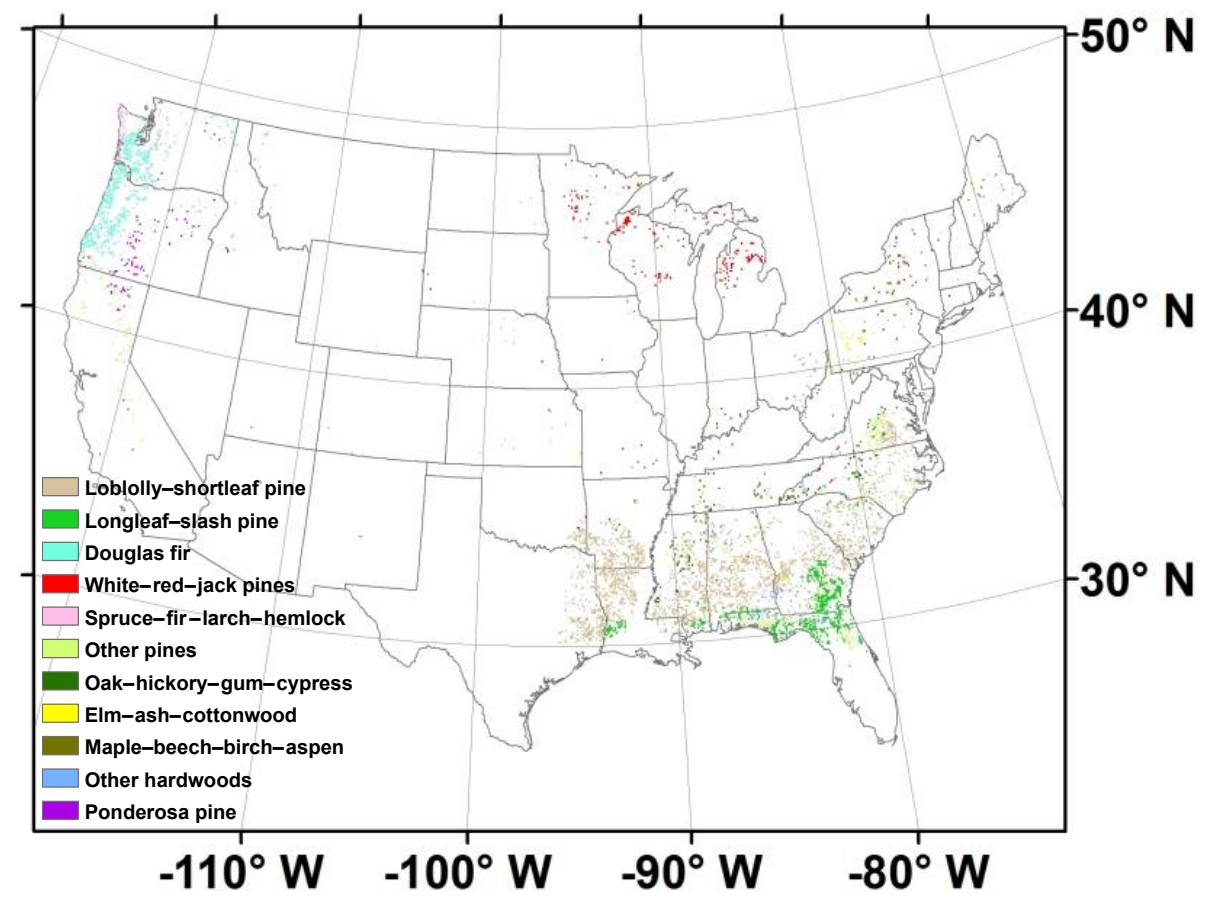

Figure 11. Spatial distribution of plantation tree species in the CONUS in 2012.

tial to increase plantation area in terms of the small fraction of plantation forests $(8.65 \%)$ currently existing in the CONUS. With suitable climate and geophysical environmental conditions, the southern US is the major plantation forest base, with plantation forests accounting for $19.34 \%$ of total forestland.

Many short- and long-term field experiments in the CONUS, especially in the South, are ongoing to monitor intensive management practice effects on plantation forests. The large number of available observational data has greatly improved our understanding of the impacts of forest planting and management practices on ecological and socioeconomic services. Scaling up these studies from local-scale observations to regional understanding requires a series of spatially explicit and long-term regional-national data sets that include information on various management practices, plantation distribution, environmental conditions, and vegetation maps. The first and critical step is to generate the long-term plantation distribution maps. Recognizing this, we synthesized various inventory data to generate the gridded plantation distribution and species maps during 1928-2012. There are some aspects of uncertainty in our methods in which the data sets might be unable to track the exact plantation locations; however, our data sets had a relatively high spatial resolution $(8 \mathrm{~km})$ as required for terrestrial ecosystem modeling or statistical extrapolations on regional or national scales. The detailed spatiotemporal data for plantation tree species enables future research in simulating and extrapolating the regional- or national-scale carbon, nitrogen, and water dy- namics in plantation forests based on species-specific parameters, which could further improve the mechanisms and estimation accuracy of regional Earth system models.

The future plantation area and distribution will be determined by many factors, including wood product markets, bioenergy technology and biofuel prices, food supply and demand, environmental policies, and other socioeconomic factors (Wear and Greis, 2012). The plantation forest area in the South is projected to increase to $26 \%$ of total forestland (high scenario; Wear and Greis, 2012). From a socioeconomic perspective, present plantation forests in the CONUS generate positive economic profits along with providing good environmental services. From a carbon credit perspective, the plantation forests in the South are regarded as a major contributor to carbon sink in the CONUS and North America (Hayes et al., 2012; King et al., 2012; Tian et al., 2012, 2014); however, recent studies (Achat et al., 2015a, b; Nave et al., 2010) suggested that the shorter rotation age and some intensive management practices (e.g., site preparation for soil bedding, slash burning, and harvest residue raking) might reduce soil carbon stocks in plantation forests, implying that plantation forests could be a carbon source. From the hydrological perspective, plantation forests may increase water use and alter the water cycle due to higher productivity and management practices (e.g., short rotation, mechanic site preparation, and drainage), especially in the regions with strong precipitation limitation (Vose et al., 2012). From the perspective of nutrient cycling, plantation management practices could change soil available-total nitrogen, soil nitrous oxide emis- 
sion, vegetation nitrogen, and nitrogen contents in nearby water bodies. Many past assessments have been conducted at the scale of the individual perspective; however, there is still a lack of a comprehensive assessment of plantation forests' function in mitigating future climate change by considering carbon, nitrogen, and water fluxes across broader regions. Such a comprehensive assessment is critical for determining whether the policymakers or land managers are going to plant more trees and how to best manage the forests in the CONUS (Sun and Vose, 2016).

Author contributions. GSC collected and compiled the inventory data, developed spatialization methods, and led the writing. SFP, DJH, and HQT participated in developing methods and writing the paper.

Competing interests. The authors declare that they have no conflict of interest.

Acknowledgements. This research was supported by the NASA Carbon System Monitoring Program (NX14AO73G and NNX12AP84G), NASA Interdisciplinary Science Program (NNX11AD47G and NNX14AF93G), and Auburn University IGP program.

Edited by: Hannes Grobe

Reviewed by: three anonymous referees

\section{References}

Achat, D. L., Fortin, M., Landmann, G., Ringeval, B., and Augusto, L.: Forest soil carbon is threatened by intensive biomass harvesting, Scientific Report, 5, 15991, https://doi.org/10.1038/srep15991, 2015a.

Achat, D. L., Deleuze, C., Landmann, G., Pousse, N., Ranger, J., and Augusto, L.: Quantifying consequences of removing harvesting residues on forest soils and tree growth - A meta-analysis, Forest. Ecol. Manage., 348, 124-141, https://doi.org/10.1016/j.foreco.2015.03.042, 2005 b.

Albaugh, T. J., Vance, E. D., Gaudreault, C., Fox, T. R., Allen, H. L., Stape, J. L., and Rubilar, R. A.: Carbon emissions and sequestration from fertilization of pine in the southeastern United States, Forest Sci., 58, 419-429, https://doi.org/10.5849/forsci.11-050, 2012.

Albaugh, T., Alvarez, J., Rubilar, R., Fox, T., Allen, H., Stape, J., and Mardones, O.: Long-term Pinus radiate productivity gains from tillage, vegetation control, and fertilization, Forest Sci., 61, 800-808, https://doi.org/10.5849/forsci.14-207, 2015.

Allen, H. L., Fox, T. R., and Campbell, R. G.: What is ahead for intensive pine plantation silviculture in the South? South. J. Appl. For., 29, 62-69, 2005.

Chen, G., Tian, H., Zhang, C., Liu, M., Ren, W., Zhu, W., Chappelka, A., Prior, S. A., and Lockaby, G.: Drought in the southern United States over the last century: Variability and its im- pacts on terrestrial ecosystem productivity and carbon storage, Climatic Change, 114, 379-397, https://doi.org/10.1007/s10584012-0410-z, 2012.

Chen, G., Pan, S., Hayes, D. J., and Tian, H.: Spatial and temporal patterns of plantation forests in the United States since the 1930s, links to gridded result files in different formats, PANGAEA, https://doi.org/10.1594/PANGAEA.873558, 2017.

Escalante Fernandez, R., Monreal Rangel, S., Stanturf, J., Arseneau, C., and Nantel, P.: Forest plantations in North America. Report to the North American Forestry Commission, 26 pp., 2002.

FAO: Global Forest Resources Assessment 2005, UN Food and Agriculture Organization, Rome, Italy, available at: http://www. fao.org/forestry/fra/fra2005/en/, last access: 26 July 2017, 2005.

FAO: Global Forest Resources Assessment 2015, UN Food and Agriculture Organization, Rome, Italy, available at: http://www. fao.org/3/a-i4808e.pdf, last access: 26 July 2017, 2015.

Fox, T. R., Jokela, E. J., and Allen, H. L.: The evolution of pine plantation silviculture in the Southern United States, in: Gen. Tech. Rep. SRS-75, U.S. Department of Agriculture, Forest Service, Southern Research Station, Asheville, NC, chap. 8, 63-82, 2004.

Fox, T., Allen, H., Albaugh, T., Rubilar, R., and Carlson, C.: Tree nutrition and forest fertilization of pine plantations in the southern United States, South. J. Appl. For., 31, 5-11, 2007.

Frederick, K. K. and Sedjo, R. A.: America's renewable resources: historical trends and current challenges, Resources for the $\mathrm{Fu}$ ture, Washington, DC, 296 pp., 1991.

Gyawali, N. and Burkhart, H. E.: General response functions to silvicultural treatments in loblolly pine plantations, Can. J. Forest Res., 45, 252-265, https://doi.org/10.1139/cjfr-2014-0172, 2015.

Hayes, D. J., Turner, D. P., Stinson, G., McGuire, A. D., Wei, Y., West, T. O., Heath, L. S., Dejong, B., McConkey, B. G., Birdsey, R. A., Kurz, A. W., Jacobson, A. R., Huntzinger, D. N., Pan, Y., Post, W. M., and Cook, R. B.: Reconciling estimates of the contemporary North American carbon balance among terrestrial biosphere models, atmospheric inversions, and a new approach for estimating net ecosystem exchange from inventory-based data, Global Change Biol., 18, 1282-1299, https://doi.org/10.1111/j.1365-2486.2011.02627.x, 2012.

Hoover, C., Birdsey, R., Goines, B., Lahm, P., Marland, G., Nowak, D., Prisley, S., Reinhardt, E., Skog, K., Skole, D., Smith, J., Trettin, C., and Woodall, C.: Chapter 6: Quantifying greenhouse gas sources and sinks in managed forest systems, in: Quantifying greenhouse gas fluxes in agriculture and forestry: Methods for entity-scale inventory, Tech. Bull. 1939, edited by: Eve, M., Pape, D., Flugge, M., Steele, R., Man, D., Riley-Gilbert, M., and Biggar, S., Office of the Chief Economist, U.S. Department of Agriculture, Washington, DC, 6-1-6.114, 2014.

Jokela, E. J., Dougherty, P. M., and Martin, T. A.: Production dynamics of intensively managed loblolly pine stands in the southern United States: a synthesis of seven long-term experiments, Forest Ecol. Manag., 192, 117-130, https://doi.org/10.1016/j.foreco.2004.01.007, 2004.

Jokela, E. J., Martin, T. A., and Vogel, J. G.: Twenty-five years of intensive forest management with southern pines: important lessons learned, J. Forest., 107, 338-347, 2010.

King, A. W., Hayes, D. J., Huntzinger, D. N., West, T. O., and Post, W. M.: North America carbon dioxide sources and sinks: magni- 
tude, attribution, and uncertainty, Front. Ecol. Environ., 10, 512519, https://doi.org/10.1890/120066, 2012.

Nave, L. E., Vance, E. D., Swanston, C. W., and Curtis, P. S.: Harvest impacts on soil carbon storage in temperate forests, Forest Ecol. Manag., 259, 857-866, https://doi.org/10.1016/j.foreco.2009.12.009, 2010.

O’Connell, B. M., LaPoint, E. B., Turner, J. A., Ridley, T., Pugh, S. A., Wilson, A. M., Waddell, K. L., and Conkling, B. L.: The Forest Inventory and Analysis Database: Database Description and User Guide for Phase 2 (Version 6.0.2), U.S. Department of Agriculture, Forest Service, 748 pp., available at: https://www. fia.fs.fed.us/library/database-documentation, last access: 26 July 2017.

Oliver, C. D.: The future of the forest management industry: Highly mechanized plantations and reserves or a knowledgeintensive integrated approach?, Forest. Chron., 75, 229-245, https://doi.org/10.5558/tfc75229-2, 1999.

Oswalt, S. N., Smith, W. B., Miles, P. D., and Pugh, S. A.: Forest Resources of the United States, 2012: a technical document supporting the Forest Service 2015 update of the RPA Assessment, Gen. Tech. Rep. WO-91, U.S. Department of Agriculture, Forest Service, Washington Office, Washington, DC, 218 pp., available at: https://www.srs.fs.usda.gov/pubs/gtr/gtr_wo091.pdf, last access: 26 July 2017, 2014.

Pan, S., Tian, H., Dangal, S. R. S., Yang, Q., Yang, J., Lu, C., Tao, B., Ren, W., and Ouyang, Z.: Responses of global terrestrial evapotranspiration to climate change and increasing atmospheric $\mathrm{CO}_{2}$ in the 21st century, Earth's Future, 3, 15-35, https://doi.org/10.1002/2014EF000263, 2015.

Sedjo, R. A.: From foraging to cropping: the transition to plantation forestry, and implications for wood supply and demand, Unasylva 52 (2001/1) No. 204, available at: http://www.fao. org/DOCREP/003/X8820E/x8820e06.htm\#P0_0, last access: 26 July 2017, 2001.

Smith, W. B., Miles, P. D., Perry, C. H., and Pugh, S. A.: Forest Resources of the United States, 2007, Gen. Tech. Rep. WO-78, U.S. Department of Agriculture, Forest Service, Washington Office, Washington, DC, 336 pp., available at: https://www.fs.fed. us/nrs/pubs/gtr/gtr_wo78.pdf, last access: 26 July 2017, 2009.

Stanturf, J. A. and Zhang, D.: Plantations forests in the United States of America: past, present and future, XII Word Forestry Congress, Quebec City, Canada, available at:http://www.fao.org/ docrep/article/wfc/xii/0325-b1.htm, last access: 26 July 2017, 2003.

Sun, G. and Vose, J. M.: Forest management challenges for sustaining water resources in the Anthropocene, Forests, 7, 68-80, https://doi.org/10.3390/f7030068, 2016.
Sun, G., Zhou, G., Zhang, Z., Wei, X., McNulty, S., and Vose, J. M.: Potential water yield reduction due to forestation across China, J. Hydrol., 328, 548-558, https://doi.org/10.1016/j.jhydrol.2005.12.013, 2006.

Tian, H., Chen, G., Zhang, C., Liu, M., Sun, G., Chappelka, A., Ren, W., Xu, X., Lu, C., Pan, S., Chen, H., Hui, D., McNulty, S., Lockaby, G., and Vance, E.: Century-scale response of ecosystem carbon storage and flux to multifactorial global change in the Southern United States, Ecosystems, 15, 674-694, https://doi.org/10.1007/s10021-012-9539-x, 2012.

Tian, H., Chen, G., Lu, C., Xu, X., Hayes, D., Ren, W., Pan, S., Huntzinger, D., and Wofsy, S.: North American terrestrial $\mathrm{CO}_{2}$ uptake largely offset by $\mathrm{CH}_{4}$ and $\mathrm{N}_{2} \mathrm{O}$ emissions: toward a full accounting of the greenhouse gas budget, Climatic Change, 129, 413-426, https://doi.org/10.1007/s10584-014-1072-9, 2014.

USDA Forest Service: National Report on Sustainable Forests 2010, FS-979, USDA Forest Service, Washington, DC, 2011.

Vance, E. D., Maguire, D. A., and Zalesny, R. S.: Research strategies for increasing productivity of intensively managed forest plantations, J. Forest., 108, 183-192, available at: https:// www.srs.fs.fed.us/pubs/ja/2010/ja_2010_vance_002.pdf, last access: 26 July 2017, 2010.

Vose, J. M., Ford, C. R., Laseter, S., Dymond, S., Sun, G., Adams, M. B., Sebestyen, S., Campbell, J., Luce, C., Amatya, D., Elder, K. H., and Scalley, T.: Can forest watershed management mitigate climate change effects on water resources, in: Revisiting Experimental Catchment Studies in Forest Hydrology, Proceedings of a Workshop held during the XXV IUGG General Assembly in Melbourne, June-July 2011, edited by: Webb, A. A., Bonell, M., Bren, L., Lane, P. N. J., McGuire, D., Neary, D, G., Nettles, J., Scott, D. F., Stednick, J., and Wang, Y., IAHS Publ. 353, Oxfordshire, UK, 12-25, 2012.

Wear, D. N. and Greis J. G.: Southern Forest Resource Assessment - Technical Report, Gen. Tech. Rep. SRS-53, U.S. Department of Agriculture, Forest Service, Southern Research Station, Asheville, NC, 635 pp., available at: https://www.srs.fs.usda.gov/ pubs/gtr/gtr_srs053.pdf, last access: 26 July 2017, 2002.

Wear, D. N. and Greis, J. G.: The Southern Forest Futures Project: summary report, Gen. Tech. Rep. SRS-GTR-168, USDA-Forest Service, Southern Research Station, Asheville, NC, 54 pp., available at: https://www.srs.fs.fed.us/pubs/gtr/gtr_srs168.pdf, last access: 26 July 2017, 2012.

Zhang, D.: Markets, policy incentives and development of forest plantation resources in the United States of America, in: The Role of Incentives in Forest Plantation Development in Asia and the Pacific, Asia-Pacific Forestry Commission, FAO Regional Office for Asia and the Pacific, Bangkok, 237-261, 2004. 